\title{
METODE PEMBELAJARAN PAI BAGI ANAK TUNARUNGU DI SDN INKLUSI
}

\author{
Husnul Khotimah \\ Institut Agama Islam Negeri (IAIN) Kediri \\ e-mail: aishaelhusna@gmail.com
}

\begin{abstract}
Abstrak: This article aims to describe the method of learning deaf children in SDN Betet 1 Kota Kediri, which is one of Inclusion Schools in Kediri. The data taken from the only one deaf student in this school, 2 special Assistance Teachers, 1 Therapist, and parents of student. By using descriptive research method and qualitative approaches, finally the reseach resulted that Personal identification of deaf children is very important. This identification is related to the level of children's hearing loss and the level of intelligence (IQ) possessed. Based on available data, the method of learning Islamic Education in SDN Inclusion is writing to learn strategies, ABA (Applied, Behavior, and Analysis) methods, demonstration methods, muroja'ah methods and speech therapy. These five learning methods can get maximum results if supported by the participation of parents as the main educator.
\end{abstract}

Artikel ini bertujuan untuk mendeskripsikan metode belajar Pendidikan Agama Islam bagi anak tunarungu di SDN Betet 1 Kota Kediri, yang merupakan salah satu Sekolah Inklusi di Kediri. Data yang diambil berasal dari satu-satunya siswa tunarungu di sekolah ini, 2 Guru Pendamping Khusus, 1 terapist, dan orang tua siswa. Dengan menggunakan metode penelitian deskriptif dan pendekatan kualitatif, akhirnya penelitian menghasilkan bahwa identifikasi anak tunarungu secara personal sangat penting dilakukan. Identifikasi ini terkait dengan tingkat disabilitas pendengaran anak dan tingkat kecerdasan (IQ) yang dimiliki. Berdasarkan data yang ada, maka metode pembelajaran Pendidikan Agama Islam di SDN Inklusi adalah strategi writing to learn, metode ABA (Applied, Behaviour, and Analysis), metode demonstrasi, metode muroja'ah dan terapi wicara. Kelima metode pembelajaran ini bisa mendapatkan hasil 
yang maksimal jika didukung oleh peran serta orang tua sebagai pendidik utama.

Kata Kunci : Learning method, Islamic education, Deaf student, Inclusion school.

\section{Pendahuluan}

Memiliki keturunan merupakan idaman dari setiap pasangan yang telah melangsungkan pernikahan. Ada beberapa pasangan yang diberi kemudahan oleh Allah SWT untuk mendapatkan keturunan secara cepat, namun ada pula yang secara terpaksa harus menunggu sekian lama untuk mendapatkannya. Tidak hanya ujian tentang rentang waktu dalam menunggu kehadiran sibuah hati saja, tetapi juga ketika buah hati terlahir dengan "ketidaksempurnaan" di mata kita. Ada beberapa orang tua yang diberikan anak dengan keistimewaan tertentu oleh Allah, yang masuk dalam kategori Anak Berkebutuhan Khusus (ABK).

Ada beberapa macam ABK, di antaranya: tunanetra (partially seeing and legally blind), tunarungu wicara (communication writing and deafness), tunagrahita (mental retardation), tunadaksa (child with phisycal disability), tunalaras (child with emotional and behavioral disorder), berkesulitan belajar (specific learning disability), hiperaktif, autis dan anak berbakat.

Menurut Mangunsong, tunarungu adalah mereka yang pendengarannya tidak berfungsi, sehingga membutuhkan pelayanan pendidikan luar biasa. ${ }^{1}$ Sedangkan menurut Murni Winarsih, tunarungu adalah seseorang yang mengalami kekurangan atau kehilangan kemampuan mendengar baik sebagian atau seluruhnya yang diakibatkan oleh tidak fungsinya sebagian atau seluruh alat pendengaran, sehingga anak tersebut

\footnotetext{
${ }^{1}$ Mangunsong F dkk, Psikologi Dan Pendidikan Anak Luar Biasa (Jakarta: LPSP UI, 1998), 66.
} 
tidak dapat menggunakan alat pendengarannya dalam kehidupan sehari-hari. ${ }^{2}$

Hal ini memberikan efek terhadap sulitnya menangkap informasi yang masuk bagi penderita ditambahkan dengan pengungkapan bahasa untuk menyampaikan apa yang diinginkan.

Anak tunarungu diklasifikasikan menjadi 5 tingkatan, yakni: ${ }^{3}$
a. Sangat ringan (light)
: $25 \mathrm{~dB}-40 \mathrm{~dB}$
b. Ringan (mild)
: $41 \mathrm{~dB}-55 \mathrm{~dB}$
c. Sedang (moderate)
: $56 \mathrm{~dB}-70 \mathrm{~dB}$
d. Berat (severe)
: $71 \mathrm{~dB}-90 \mathrm{~dB}$
e. Sangat berat (profound)
: $91 \mathrm{~dB}-$ lebih

Berdasarkan Somad dan Hernawati mengungkapkan bahwa anak tunarungu mengalami hambatan dalam perkembangan bahasanya dengan demikian pemahaman anak tunarungu terhadap bahasa sedikit sekali. ${ }^{4}$

Berdasarkan klasifikasi di atas, maka anak yang berada di level profound akan menggunakan bahasa isyarat untuk berkomunikasi dengan orang lain karena mereka memang tidak bisa menangkap bahasa sama sekali, kecuali jika dilakukan tindakan medis (operasi cangkok telinga/cochlear implant) atau alat bantu dengar yang sangat membantu dalam berkomunikasi.

Ketidakmampuan anak tunarungu ini berpengaruh pada: pertama, sulit untuk mengontrol emosi. Kedua, sulit berkomunikasi dengan orang lain terutama secara lisan sehingga anak enggan berinteraksi dan akhirnya merasa kesepian dan terisolasi. Umumnya mereka cenderung bersikap kaku dan pemalu. Namun demikian mereka tidak memiliki

2 Murni Winarsih, Intervensi Dini Bagi Anak Tunarungu Dalam Pemerolehan Bahasa (Departemen Pendidikan dan Kebudayaan, 2007), 23.

${ }^{3}$ Heri Purwanto, Pengantar Perilaku Manusia (Jakarta: EGC, 1998), 7.

4 Somad and Hernawati, Ortopendagogik Anak Tunarungu (Jakarta: Departemen Pendidikan dan Kebudayaan, 1995), 11. 
masalah dalam berinteraksi dengan orang-orang di lingkungan sekitar rumah.

Dengan kondisi yang ada, bukan berarti anak tunarungu tidak bisa mengenyam pendidikan layaknya anak normal lainnya. Pemerintah telah memberikan layanan pendidikan bagi anak tunarungu dan berbagai anak dengan ketunaan lainnya sesuai dengan hak mereka yang tertulis pada pasal 31 UUD 1945, 'Setiap warga negara berhak untuk mendapatkan pendidikan'.

Selain itu, dalam Undang-undang No 20 tahun 2003 tentang Sistem Pendidikan Nasional Pasal 32, disebutkan bahwa: "Pendidikan Khusus (pendidikan luar biasa) merupakan pendidikan bagi peserta didik yang memiliki tingkat kesulitan dalam mengikuti proses pembelajaran karena kelainan fisik, emosional, mental dan sosial."

Layanan pendidikan yang ditawarkan pemerintah adalah sistem pendidikan segregasi (sistem pendidikan di mana anak berkelainan terpisah dari sistem pendidikan anak normal). ${ }^{6}$ sistem pendidikan integrasi (sistem pendidikan yang memungkinkan anak luar biasa memperoleh kesempatan mengikuti proses pendidikan bersama dengan siswa normal agar dapat mengembangkan diri secara optimal), ${ }^{7}$ dan sistem pendidikan inklusi (penggabungan penyelenggaraan pendidikan luar biasa dan pendidikan reguler dalam satu sistem pendidikan yang di persatukan). ${ }^{8}$

\footnotetext{
5 Mohammad Effendi, Pengantar Psikopaedagogik Anak Berkelainan (Jakarta: Bumi Aksara, 2006), 1.

6 Hargio Santoso, Cara Memahami Dan Mendidik Anak Berkebutuhan (Yogyakarta: Gosyen Publishing, n.d.), 11-13.

7 Sunardi, Kecenderungan Dalam Pendidikan Luar Biasa (Jakarta: Departemen Pendidikan dan Kebudayaan, 2005), 86.

8 Wahyu Sri Ambar Arum, Perspektif Pendidikan Luar Biasa Dan Implikasinya Bagi Penyiapan Tenaga Kependidikan (Jakarta: Depdiknas, n.d.), 105.
} 
Dari ketiga layanan pendidikan di atas, sekolah inklusi sangat menarik untuk dibahas, karena didasarkan atas pandangan bahwa semua anak berhak untuk masuk ke sekolah reguler. Tugas sekolah adalah menyediakan kebutuhan semua anak dalam komunitasnya, apapun derajat kemampuan dan ketidakmampuannya. Dalam pendidikan inklusi semua perbedaan dihargai, termasuk perbedaan ras, etnik, maupun latar belakang sosial dan budaya. ${ }^{9}$

Kondisi pembelajaran di atas menjadi semakin menarik ketika materi yang dibahas adalah Pendidikan Agama Islam (PAI), yang sarat akan nilai-nilai pendidikan karakter dan kelak akan menjadi pegangan hidup dan bekal bagi setiap anak dalam menjalani kehidupan mendatang. Oleh karena itu, terdapat perbedaan strategi pembelajaran yang diterapkan guru PAI terhadap siswa yang satu dengan yang lainnya. ${ }^{10}$

Bagi pihak sekolah (dalam hal ini adalah guru Pendidikan Agama Islam), memiliki peran yang sangat penting untuk memberikan pendidikan agama bagi siswanya. Seperti tertulis dalam Q.S. Al-Zalzalah ayat 7 yang berbunyi:

Artinya: maka barang siapa yang mengerjakan kebaikan seberat zarrah niscaya dia akan melihat balasanNya. ${ }^{11}$

Sehingga, hal ini memaksa guru agar memiliki kemampuan dalam menghadapi banyaknya perbedaan peserta didik. Hal ini menyebabkan adanya penyesuaian-penyesuaian yang harus dilakukan oleh guru dalam proses pembelajaran. ${ }^{12}$

\footnotetext{
${ }^{9}$ Yuliani Nurani Sujono, Konsep Dasar Pendidikan Anak Usia Dini (Jakarta: Indeks, 2009), 169.

${ }^{10}$ M. Maftuhin and A. Jauhar Fuad, "Pembelajaran Pendidikan Agama Islam Pada Anak Berkebutuhan Khusus," Journal An-Nafs: Kajian Penelitian Psikologi 3, no. 1 (June 24, 2018): 76.

${ }^{11}$ Depag RI, Al-Qur'an Dan Terjemahannya (Jakarta: Pelita III, 1983), 1087.

12 Gavin Reid, Dyslexia and Inclusion; Classroom Approaches for Assesment, Teaching and Learning (London: David Fulton Publisher, 2005), 88.
} 
Jika guru tidak mampu menerapkan metode pembelajaran dengan tepat, maka siswa juga tidak bisa mendapatkan hasil yang maksimal. Sehingga kelompok anak tunarungu akan merasa kesulitan dalam mengikuti proses pembelajaran yang dilaksanakan anak normal. Selain itu akan muncul diskriminasi antar siswa dalam satu kelas yang akhirnya akan berdampak pada sisi psikologis anak berkebutuhan khusus.

\section{Metode Penelitian}

Metode penelitian yang digunakan adalah metode deskriptif, yakni penelitian yang digunakan untuk menganalisis data dengan cara mendeskripsikan atau menggambarkan data yang telah terkumpul sebagaimana adanya tanpa bermaksud membuat kesimpulan yang berlaku untuk umum atau generalisasi. $^{13}$

Masih menurut Sugiyono, penelitian kualitatif adalah penelitian yang berlandaskan pada filsafat postpositivisme, digunakan untuk meneliti pada kondisi objek yang alamiah, di mana peneliti sebagai instrumen kunci, analisis data bersifat induktif/kualitatif dan hasil penelitian lebih menekankan makna dari pada generalisasi.

Penelitian kualitatif pada umumnya dirancang untuk memberikan pengalaman senyatanya dan menangkap makna sebagaimana yang tercipta di lapangan penelitian melalui interaksi langsung antara peneliti dan yang diteliti. ${ }^{14}$

Teknik pengumpulan data yang digunakan :

\section{Teknik observasi}

Adalah teknik pengumpulan data dengan cara peneliti melakukan pengamatan secara langsung di lapangan. Metode

\footnotetext{
${ }^{13}$ Sugiyono, Metode Penelitian Kualitatif, Kuantitatif Dan R\&D (Bandung: Alfabeta, 2013), 147.

${ }^{14}$ Putu Laksman Pendit, Penelitian Ilmu Perpustakaan Dan Informasi: Suatu Pengantar Diskusi Epistemologi Dan Metodologi (Jakarta: JIP FS-UI, 2003), 195.
} 
observasi merupakan metode pengumpul data yang dilakukan dengan cara mengamati dan mencatat secara sistematik gejala-gejala yang diselidiki.

Objek yang akan diobservasi dalam penelitian ini adalah siswa tunarungu beserta guru, dalam hal ini adalah Guru Pendamping Khusus (GPK), Guru Pendidikan Agama Islam dan terapist. Selain itu, kegiatan pembelajaran baik di dalam kelas maupun di luar kelas.

2. Teknik wawancara,

Adalah percakapan yang dilakukan oleh dua orang atau lebih yaitu wawancara yang akan mengajukan pertanyaan dan orang yang akan diwawancarai yang akan memberikan jawaban atas pertanyaan yang akan diajukan. ${ }^{15}$

Wawancara dilakukan untuk memperoleh data mengenai siswa tunarungu, metode pembelajaran yang digunakan guru dalam proses penyampaian materi serta sejauh mana peran orang tua dalam mendukung proses pembelajaran siswa ketika berada di rumah. Sehingga, guru dan orang tua siswa tunarungu menjadi orang yang diwawancarai.

3. Teknik dokumentasi.

Merupakan catatan peristiwa yang sudah berlalu. Dokumen bisa berbentuk tulisan, gambar, atau karya-karya monumental dari seorang. Dokumen yang berbentuk tulisan misalnya catatan harian, sejarah kehidupan (life histories), ceritera, biografi, peraturan, kebijakan. Dokumen yang berbentuk gambar misalnya foto, gambar hidup, sketsa dan lain-lain. Dokumen yang berbentuk karya misalnya karya seni, yang dapat berupa gambar, patung, film dan lain-lain. Studi dokumen merupakan pelengkap dari penggunaan

15 Lexy J. Moleong, Metode Penelitian Kualitatif (Bandung: Remaja Rosdakarya, 2002), 186. 
metode observasi dan wawancara dalam penelitian kualitatif. ${ }^{16}$

Hasil dokumentasi yang diperoleh meliputi data anak berkebutuhan khusus (ABK) di SDN Betet 1 Kota Kediri beserta klasifikasinya, data seluruh guru, baik itu PNS atau non-PNS, Guru Pendamping Khusus (GPK), dan terapist, foto pelaksanaan proses pembelajaran baik di kelas maupun di luar kelas.

a. Data primer yang didapat berupa hasil wawancara dengan Guru Pendamping Khusus, Guru Pendidikan Agama Islam dan terapist

b. Data sekunder yang didapat berupa dokumen-dokumen sekolah yang meliputi arsip sekolah, catatan, gambar atau foto- foto, dan bahan referensi lainnya yang mendukung penelitian ini

4. Teknik triangulasi, teknik pengumpulan data yang bersifat menggabungkan dari berbagai teknik pengumpulan data dan sumber data yang telah ada. ${ }^{17}$ Teknik ini digunakan untuk mengecek keabsahan data dengan kata lain, teknik pemeriksaan keabsahan data yang memanfaatkan sesuatu yang lain dalam membandingkan hasil wawancara terhadap objek penelitian. ${ }^{18}$

Langkah selanjutnya adalah menganalisis data, yakni proses mengatur urutan data, kemudian mengorganisasikannya ke dalam suatu pola, kategori, dan satuan uraian dasar.

Tujuan dari analisis data adalah untuk mendeskripsikan data sehingga bisa dipahami, lalu untuk membuat kesimpulan atau menarik kesimpulan mengenai karakteristik populasi berdasarkan data yang didapatkan dari sampel, biasanya dibuat berdasarkan pendugaan dan pengujian hipotesis

\footnotetext{
${ }^{16}$ Sugiyono, Metode Penelitian Kualitatif, Kuantitatif Dan R\&D, 240.

17 HB Soetopo, Metodologi Penelitian Kualitatif Dasar Teori Dan Terapannya Dalam Penelitian (Surakarta: UNS Press, 2002), 92.

${ }^{18}$ Moleong, Metode Penelitian Kualitatif, 330.
} 


\section{Hasil Penelitian dan Pembahasan}

SDN Betet 1 Kota Kediri adalah salah satu Sekolah Dasar Negeri yang ditunjuk oleh Pemerintah Kota Kediri untuk melaksanakan kurikulum pembelajaran inklusi. Dengan kata lain, di sekolah ini juga menerima anak-anak berkebutuhan khusus agar mereka bisa mendapatkan hak pendidikan selayaknya anak normal lainnya. Setidaknya, ada 69 anak berkebutuhan khusus yang mengenyam pendidikan di sini dengan berbagai macam "kebutuhannya", di antaranya adalah sebagai berikut ${ }^{19}$ :

Tabel 1: Data Anak Berkebutuhan Khusus (ABK) SDN Betet 1 Kota Kediri

\begin{tabular}{|l|l|c|}
\hline NO & \multicolumn{1}{|c|}{ KEBUTUHAN KHUSUS } & JUMLAH ANAK \\
\hline 1 & Tuna Grahita Ringan & 20 \\
\hline 2 & Tuna Grahita Sedang & 12 \\
\hline 3 & Autis & 3 \\
\hline 4 & Embisil lambat & 1 \\
\hline 5 & $\begin{array}{l}\text { Gangguan Konsentrasi dan } \\
\text { bicara }\end{array}$ & 1 \\
\hline 6 & Lambat Belajar & 16 \\
\hline 7 & Tuna Laras & 2 \\
\hline 8 & Debil & 1 \\
\hline 9 & Tuna Daksa sedang & 3 \\
\hline 10 & Hiperaktif & 2 \\
\hline 11 & Down Syndrome & 1 \\
\hline 12 & Tuna rungu & 69 \\
\hline & \multicolumn{1}{|c|}{ JUMLAH } \\
\hline
\end{tabular}

Satu-satunya siswa tunarungu di SDN Betet 1 Kota Kediri adalah MK. Siswa kelahiran Kediri, 1 Desember 2015 ini mengalami kecatatan sejak lahir. Yakni, ketika dalam masa kehamilan, sang ibu terkena virus toxo dan rubella, yang jika tidak ada penanganan sejak awal, akan mengakibatkan

\footnotetext{
${ }^{19}$ Data didapat dari dokumen sekolah, SDN Betet 1 Kota Kediri berupa arsip dan dokumentasi.
} 
kecacatan pada anak. Namun, hal ini baru teridentifikasi oleh orang tuanya pada usia 5 tahun, yakni ketika ia belum mampu berbicara layaknya anak seusianya. Pada awalnya, kedua orang tuanya menganggap apa yang terjadi hanyalah keterlambatan bicara seperti anak pada umumnya. Sehingga, dia hanya menjalani terapi dan diberi obat-obatan tradisional dan herbal yang berasal dari ahlinya. Sesuai saran yang diberikan oleh neneknya, selaku pengasuh sehari-hari. ${ }^{20}$

Namun, ternyata hal ini tidak mendapatkan hasil. Orang tuanya berinisiatif untuk membawa MK ke Dokter Spesialis THT di Rumah Sakit, dan dirujuk ke Rumah Sakit Dr. Soetomo Surabaya. Di sana ada serangkaian tes kesehatan yang dijalani, yang di dalamnya terdapat tes telinga atau yang sering disebut dengan tes audiometri. Hasil tes tersebut menyatakan bahwa MK tergolong dalam kategori tuli berat $(61-90 \mathrm{db})$, yakni $88 \mathrm{db}$. Dokter memberikan saran kepada orang tua pasien, yakni memakai alat bantu dengar cochlear implant.

Cochlear implant adalah prostesis alat pendengaran yang terdiri dari dua komponen, yaitu komponen eksternal (mikropon dan speech processor) yang dipakai oleh pengguna, dan komponen internal (rangkaian elektroda yang melalui pembedahan dimasukkan ke dalam cochlea (ujung organ pendengaran) di telinga bagian dalam. Komponen eksternal dan internal tersebut dihubungkan secara elektrik. Prostesis cochlear implant dirancang untuk menciptakan rangsangan pendengaran dengan langsung memberikan stimulasi elektrik pada syaraf pendengaran.

\footnotetext{
${ }^{20}$ Perlu diketahui bahwa ayah MK adalah seorang PNS, dan ibunya adalah seorang guru di salah satu Madrasah di Kota Kediri. Karena kesibukan orang tuanya inilah, maka Kamila di titipkan ke neneknya. Ketika sore, orang tua menjemputnya untuk pulang ke rumah.
} 
Operasi (pembedahan) baru dilakukan ketika MK berusia 7 tahun, karena terkendala biaya yang sangat tinggi. ${ }^{21}$ Sebelum operasi, Dokter meminta Psikolog untuk memberikan tes IQ. Hal ini dikarenakan hasil tes IQ sangat mempengaruhi tingkat berpikir anak pasca operasi. Semakin tinggi IQ anak tunarungu, maka ia akan tumbuh dan berkembang sesuai dengan usianya, sama seperti anak normal lainnya, sebaliknya, semakin rendah tingkat IQ nya, maka perkembangannya juga akan sedikit terlambat.

Hasil tes IQ dari MK adalah 98, termasuk kedalam kategori rata-rata, tidak terlalu jenius, tidak pula dalam kategori idiot. Dokter mengatakan bahwa jika operasi tetap berlanjut, maka perkembangan MK tidak bisa maksimal, (seperti anak normal lainnya), karena terlambat operasi (seharusnya operasi dilaksanakan pada masa golden age/1-5 tahun). Namun, kalau tidak dioperasi maka perkembangan MK jauh dari kata baik. Akhirnya operasi dilaksanakan.

Hasilnya, ketika MK berusia 12 tahun :

1. Sudah mampu menangkap suara dan mendengar, (dengan bantuan alat luar yang menempel di daun telinga tentunya),

2. Mampu mengucapkan sepatah dua patah kata (namun sangat sulit merangkai kata, kondisi Kamila selain tunarungu juga tunawicara),

3. Mampu mengontrol emosi kejiwaannya. (ketika masih kecil, belum dilakukan operasi, dia tidak mampu mengungkapkan apa yang ia inginkan sehingga orang di sekelilingnya tidak paham terhadap apa yang ia inginkan). Seiring berjalannya waktu, dia mampu mendengar dan sedikit bisa mengolah apa yang didengar dan akhirnya diucapkan, walaupun belum sempurna.

\footnotetext{
${ }^{21}$ Biaya operasi yang dibutuhkan sekitar Rp. 200 juta, sangat mahal karena alat yang ditanam di dalam telinganya diimpor langsung dari Australia.
} 
4. Karena operasi terlambat dilakukan, ditambah dengan tingkat IQ yang berada di posisi rata-rata, maka cara berpikir MK setara dengan anak berusia 5-6 tahun, atau anak TK. Sehingga, jika pada umumnya, usia 12 tahun berada di kelas 6 SD, di SDN Betet 1 dia berada di kelas 4 SD, namun, metode pembelajarannya masih harus seperti anak TK. ${ }^{22}$

Dari kondisi subjek utama penelitian di atas, maka metode pembelajaran PAI yang dijalani oleh MK di SDN Betet 1 Kediri selaku penyelenggara sekolah Inklusi adalah sebagai berikut:

1. Strategi writing to learn, strategi ini dapat meningkatkan literasi siswa dalam belajar di kelas melalui menulis mereka belajar untuk memperoleh pemahaman konsep dan keterampilan serta berlatih untuk berkomunikasi tetapi tidak ditekankan untuk melatih ejaan atau tata bahasa. ${ }^{23}$

Contoh sederhana yang dilakukan MK ketika pembelajaran PAI adalah menulis Arab secara sederhana. Materi ini diberikan kepada semua siswa, baik itu siswa tunarungu ataupun siswa normal. Ditempatkan dalam satu ruangan kelas yang mana didampingi oleh 2 orang guru, yakni guru kelas dan guru pendamping khusus. Anak tuna rungu dibimbing langsung oleh GPK dalam hal pemberian tugas dan pelaksanaanya karena instruksi yang diberikan oleh guru kelas tidak akan sampai informasinya kepada anak tuna rungu. Sedangkan hasil pekerjaannya dikoreksi oleh guru kelas

2. Metode ABA (Applied, Behaviour, and Analysis), yakni ilmu yang menggunakan prosedur perubahan perilaku, untuk membantu individu membangun kemampuan dengan ukuran nilai-nilai yang ada di individu. Dalam penyampaian materi,

\footnotetext{
22 Tingkat pemahamannya sangat lambat, membutuhkan waktu dan proses yang lama.

${ }^{23}$ Sri Poedjiastuti, Kit-Kimia Dengan Strategi Writing to Learn Untuk Siswa SMALB Tunarungu (Surabaya: Prosiding Seminar Nasional Kimia UNESA, 2012), B179-88.
} 
guru harus menjaga kontak mata yang lama dan konsisten, tanpa marah, tegas dalam memberikan arahan tetapi lembut, serta memberikan reward ketika bisa memenuhi target pembelajaran. $^{24}$

Penerapan metode ini dalam pembelajaran MK adalah guru menjelaskan materi tentang salah satu gerakan shalat, yakni ruku', yang posisinya adalah $90^{\circ}$. Ketika posisi ruku' MK belum sempurna, maka guru memberitahukan kesalahannya dengan lemah lembut. Katika gerakannya sudah benar, maka guru langsung memberikan 2 jempol pada MK.

3. Metode demonstrasi, metode di mana cara penyajian bahan pelajaran dengan meragakan atau mempertunjukkan kepada siswa suatu proses situasi, atau benda tertentu yang sedang dipelajari, baik sebenarnya ataupun tiruan yang sering disertai penjelasan lisan. ${ }^{25}$

Kegiatan rutin shalat dhuha berjama'ah merupakan salah satu contoh metode demonstrasi ini diterapkan dalam pembelajaran PAI di sekolah dasar inklusi. Guru bertindak menjadi imam dan murid (secara bergilir, dikarenakan luas musholla yang dimiliki sekolah tidak terlalu besar) sebagai makmum.

4. Metode muroja'ah. Secara bahasa muroja'ah berasal dari bahasa Arab roja'a yarji'u yang artinya kembali. ${ }^{26}$ Sedangkan secara istilah ialah mengulang kembali atau mengingat kembali sesuatu yang telah dihafalnya, atau metode pengulangan berkala. ${ }^{27} \mathrm{Hal}$ ini sesuai dengan teori koneksionisme milik Thorndike, yang mengatakan bahwa belajar adalah pembentukan hubungan antara stimulus dan

\footnotetext{
${ }^{24}$ Sutardi Rudi, Autisme Dan ABA/Metode Loovas (Jakarta: Jakarta Medical Center, 2002), 4.

${ }^{25}$ Daryanto, Media Pembelajaran (Yogyakarta: Gava Media, 2010), 403.

${ }^{26}$ Mahmud Yunus, Kamus Arab-Indonesia (Jakarta: Hidakarya Agung, 1989), 138.

${ }^{27}$ Alpiyanto, Menjadi Juara Dan Berkarakter (Bekasi: Tujuh Samudera, 2013), 184.
} 
respon dan pengalaman-pengalaman itu memperbesar peluang timbulnya respon benar. ${ }^{28}$

Setiap kali akan memulai pembelajaran, Guru selalu mengajak seluruh siswanya membaca al-Fatihah bersamasama dilanjut dengan do'a sebelum belajar. Hal ini dilakukan setiap hari dengan tujuan agar semua siswa mempunyai kebiasaan tersebut yang pada akhirnya bisa melekat kedalam jiwa mereka. Dalam konteks ini, tidak ada pemisahan antara siswa normal dengan siswa berkebutuhan khusus, semua siswa tanpa terkecuali berada dalam satu kelas (full inclussion class). Guru yang mengelola kelas juga hanya satu saja

5. Terapi wicara, suatu ilmu yang mempelajari perilaku komunikasi normal/abnormal yang dipergunakan untuk memberikan terapi pada penderita gangguan komunikasi yaitu kelainan kemampuan bahasa, bicara, suara, irama/kelancaran, sehingga penderita mampu berinteraksi dengan lingkungan secara wajar.

Jadwal terapi wicara MK di sekolah adalah setiap hari Senin. Didampingi oleh terapist, perkembangan penguasaan bahasa menjadi fokus dalam terapi wicara yang dijalani. Berikut adalah Buku Pendamping Khusus, yang berisi target pembelajaran dalam satu semester. Standart materi pembelajaran disesuaikan dengan kemampuan MK yang sudah diketahui ketika tes masuk sekolah dasar inklusi.

Tabel 2: Buku Pendamping Khusus ABK

Nama siswa :

\begin{tabular}{|c|l|c|c|c|c|c|}
\hline \multirow{2}{*}{ No } & \multicolumn{1}{|c|}{ Aktifitas } & \multicolumn{5}{|c|}{ Minggu ke- } \\
\cline { 3 - 7 } & & 1 & 2 & 3 & 4 & 5 \\
\hline 1 & Mengucapkan salam & & & & & \\
\hline 2 & Melafalkan doa sebelum belajar & & & & & \\
\hline
\end{tabular}

${ }^{28}$ Dimyati, Guru Dalam Proses Belajar Mengajar (Jakarta: Bumi Aksara, 2004), 39. 


\begin{tabular}{|c|l|l|l|l|l|l|}
\hline 3 & Menirukan suara angka 1-20 & & & & & \\
\hline 4 & Membaca buku seri A & & & & & \\
\hline 5 & Hafalan Q.S. Al-Ikhlas & & & & & \\
\hline 6 & Menyebutkan warna-warna & & & & & \\
\hline 7 & Menyebutkan gambar di sekitar & & & & & \\
\hline 8 & Penjumlahan angka 1-20 & & & & & \\
\hline 9 & $\begin{array}{l}\text { Motorik halus (menggunting dan } \\
\text { menempel) }\end{array}$ & & & & & \\
\hline 10 & Motorik kasar & & & & & \\
\hline
\end{tabular}

Guru bertugas memberikan tanda (+) dalam buku penilaian siswa, jika dirasa mereka mampu melakukannya. Dan akan diberi tanda silang (-), jika tidak mampu. Buku Pendamping Khusus ini selanjutnya akan diberikan kepada orang tua siswa dengan harapan agar orang tua mengetahui perkembangan pembelajaran di sekolah dan akhirnya bisa bekerja sama dengan pihak sekolah melalui mengulang pembelajaran yang sudah diajarkan disekolah.

\section{Penutup}

Untuk menentukan metode pembelajaran Pendidikan Agama Islam yang tepat bagi siswa tunarungu di Sekolah Dasar Inklusi pertama dilakukan adalah identifikasi subjek. Dalam hal ini melibatkan banyak pihak, mulai dari psikolog (untuk mengetahui tingkat kecerdasan/IQ siswa), guru, (bisa guru kelas/guru pendamping khusus), terapist, dan juga membutuhkan surat keterangan dari dokter yang berisi tentang kondisi kesehatan telinga siswa tunarungu. Seberapa kuat pendengaran yang dimilikinya.

Setelah semua teridentifikasi, maka barulah menentukan metode pembelajaran yang cocok untuk siswa tersebut. Dalam penelitian ini, siswa sebenarnya berada di level prouf (berat), 90db. Namun ketika usia 7 tahun menjalani operasi cochlear implant, atau sering disebut dengan cangkok gendang telinga. 
Sehingga dia mampu mendengar dan mampu mengucapkan lafal walaupun agak susah.

Metode pembelajaran Pendidikan Agama Islam yang diterapkan adalah 1. Strategi Writing to Learn, 2. Metode ABA, 3. Metode demonstrasi, 4. Metode muroja'ah, dan 5. Terapi wicara. Dari kelima metode pembelajaran di atas, masih bisa dikembangkan kedalam metode-metode lainnya, sesuai dengan materi yang akan disampaikan kepada siswa. Sehingga diharapkan bisa menghasilkan lulusan Sekolah Dasar Inklusi yang cerdas intelektualnya dan spiritualnya.

\section{Daftar Rujukan}

Alpiyanto. Menjadi Juara Dan Berkarakter. Bekasi: Tujuh Samudera, 2013.

Arum, Wahyu Sri Ambar. Perspektif Pendidikan Luar Biasa Dan Implikasinya Bagi Penyiapan Tenaga Kependidikan. Jakarta: Depdiknas, 2005.

Daryanto. Media Pembelajaran. Yogyakarta: Gava Media, 2010.

Dimyati. Guru Dalam Proses Belajar Mengajar. Jakarta: Bumi Aksara, 2004.

Effendi, Mohammad. Pengantar Psikopaedagogik Anak Berkelainan. Jakarta: Bumi Aksara, 2006.

F, Mangunsong, dkk. Psikologi Dan Pendidikan Anak Luar Biasa. Jakarta: LPSP UI, 1998.

Maftuhin, M., and A. Jauhar Fuad. "Pembelajaran Pendidikan Agama Islam Pada Anak Berkebutuhan Khusus." Journal An-Nafs: Kajian Penelitian Psikologi 3, no. 1 (June 24, 2018): 76-90-76-90.

Moleong, Lexy J. Metode Penelitian Kualitatif. Bandung: Remaja Rosdakarya, 2002.

Pendit, Putu Laksman. Penelitian Ilmu Perpustakaan Dan Informasi: Suatu Pengantar Diskusi Epistemologi Dan Metodologi. Jakarta: JIP FS-UI, 2003. 
Poedjiastuti, Sri. Kit-Kimia Dengan Strategi Writing to Learn Untuk Siswa SMALB Tunarungu. Surabaya: Prosiding Seminar Nasional Kimia UNESA, 2012.

Purwanto, Heri. Pengantar Perilaku Manusia. Jakarta: EGC, 1998.

Reid, Gavin. Dyslexia and Inclusion; Classroom Approaches for Assesment, Teaching and Learning. London: David Fulton Publisher, 2005.

RI, Depag. Al-Qur'an Dan Terjemahannya. Jakarta: Pelita III, 1983.

Rudi, Sutardi. Autisme Dan ABA/Metode Loovas. Jakarta: Jakarta Medical Center, 2002.

Santoso, Hargio. Cara Memahami Dan Mendidik Anak Berkebutuhan. Yogyakarta: Gosyen Publishing, 2012.

Soetopo, HB. Metodologi Penelitian Kualitatif Dasar Teori Dan Terapannya Dalam Penelitian. Surakarta: UNS Press, 2002.

Somad, and Hernawati. Ortopendagogik Anak Tunarungu. Jakarta: Departemen Pendidikan dan Kebudayaan, 1995.

Sugiyono. Metode Penelitian Kualitatif, Kuantitatif Dan $R \& D$. Bandung: Alfabeta, 2013.

Sujono, Yuliani Nurani. Konsep Dasar Pendidikan Anak Usia Dini. Jakarta: Indeks, 2009.

Sunardi. Kecenderungan Dalam Pendidikan Luar Biasa. Jakarta: Departemen Pendidikan dan Kebudayaan, 2005.

Winarsih, Murni. Intervensi Dini Bagi Anak Tunarungu Dalam Pemerolehan Bahasa. Departemen Pendidikan dan Kebudayaan, 2007.

Yunus, Mahmud. Kamus Arab-Indonesia. Jakarta: Hidakarya Agung, 1989. 